\author{
PAWEE ZAJĄC \\ https://orcid.org/0000-0003-1764-9976 \\ Wydział Teologiczny, Uniwersytet \\ im. Adama Mickiewicza w Poznaniu
}

\title{
O RELIGII POCZCIWYCH LUDZI STANISŁAWA KONARSKIEGO - MIĘDZY HISTORIOGRAFIĄ A NOWYMI USTALENIAMI NA PODSTAWIE AKT KONGREGACJI ŚWIĘTEGO OFICJUM*
}

\begin{abstract}
Abstrakt: W historiografii przeważa opinia, że oskarżenie książki Stanisława Konarskiego 0 religii poczciwych ludzi jako zawierającej błędy doktrynalne było przesadą niechętnych autorowi kręgów. Nie potrafiono jednak dotąd opisać następstw denuncjacji złożonej przez nuncjusza Angelo Marię Duriniego w Rzymie, ani też genezy łacińskiej wersji dzieła. Wykorzystane po raz pierwszy źródła archiwalne Kongregacji Doktryny Wiary pozwalają na szczegółowy opis procesu, jaki miał miejsce w Świętym oficjum. Zlecono tam włoskie i łacińskie tłumaczenie książki, poddano je ocenie rzymskich teologów, zalecono Konarskiemu precyzyjną korektę oraz przygotowanie drugiego poprawionego wydania. Oczyszczono go z wielu zarzutów postawionych mu przez teologów w Polsce, lecz zakwalifikowano książkę do indeksu ksiąg zakazanych, o ile autor nie zgodzi się na jej poprawienie.
\end{abstract}

Abstract: The prevailing opinion in historiography is that the accusation of Stanisław Konarski's book 0 religii poczciwych ludzi (On the Religion of Honest Men) as containing doctrinal errors was an exaggeration of his enemies. However, it was impossible to describe the consequences of the denunciation made by Nuncio Durini in Rome and to explain the genesis of the Latin version of the book. The archival sources of the Congregation for the Doctrine of the Faith, used for the first time, allow for a detailed description of the process that took place in the Holy office. The Italian and Latin translations of the book were commissioned, Roman theologians reviewed its contents, and Konarski was instructed to make precise corrections and to prepare a second revised edition. He was cleared of many charges made against him by the theologians in Poland, but the book was to be included in the index of prohibited books,

* Tekst powstał w ramach projektu badawczego NCN nr 2019/35/B/HS3/02063, pt. „Stanisław Konarski i rzymska Kongregacja Świętego Oficjum - edycja dokumentacji procesu w sprawie podejrzeń o herezję w dziele Myśli chrześcijańskie o religii poczciwych ludzi". 
Decyzja ta pozostała jednak utajniona, ponieważ autor poddał się nakazowi i przygotował drugie poprawione wydanie w języku łacińskim.

Słowa kluczowe: Stanisław Konarski, Angelo Maria Durini, nuncjatura, Święte Oficjum, indeks ksiąg zakazanych, deizm, Oświecenie w Polsce, Kontroświecenie. should the author persist in his expressions. This decision, however, remained secret as the author complied with the order and prepared a second revised edition in Latin.

Keywords: Stanisław Konarski, Angelo Maria Durini, nunciature, Holy Office, index of prohibited books, deism, Enlightenment in Poland, Counter-Enlightenment.

Władysław Konopczyński, oddając do druku biografię Stanisława Konarskiego, wyraził ubolewanie, że publikuje dzieło niedoskonałe - zbyt wiele źródeł uległo zniszczeniu lub pozostawało w archiwach, do których nie uzyskał dostępu. W Przedmowie pozdrawiał badaczy przyszłych pokoleń (vivant sequentes!), licząc na to, że oni będą mogli wykorzystać dalsze fragmenty korespondencji lub odnajdą zaginione pisma uczonego pijara i wypełnią barwami te części biografii, które w 1926 r. musiały pozostać zaledwie szkicem ${ }^{1}$.

Niemal sto lat później trzeba stwierdzić, że pewne aspekty życiorysu Stanisława Konarskiego wciąż intrygują i niosą ze sobą ważne pytania. Należy do nich m.in. zagadnienie genezy, znaczenia oraz recepcji jednej z ostatnich jego prac, Myśli chrześcijańskich o religii poczciwych ludzi², mającej być w zamierzeniu autora polemiką z deizmem i wolnomyślicielstwem oraz apologią światopoglądu chrześcijańskiego. Kolejni badacze pochylali się nad tą książką już od końca XVIII w., stając nieraz w ogniu polemiki, którą pod koniec XIX w. zreferował Teodor Nacher ${ }^{3}$. W minionym stuleciu to samo czynili, choć mniej polemicznie: Władysław Konopczyński, Juliusz Nowak-Dłużewski, Tomasz Chachulski ${ }^{4}$ oraz badacze kultury intelektualnej Rzeczypospolitej XVIII w.: Tadeusz Sinko, Wiktor Wąsik czy Henryk Hinz ${ }^{5}$. Na progu obecnego stulecia Myślom chrześcijańskim

${ }^{1}$ W. Konopczyński, Stanisław Konarski, Warszawa 1926, s. VII-XI [Przedmowa].

2 S. Konarski, O religii poczciwych ludzi, Warszawa 1769. Rozszerzony tytuł (Myśli chrześcijańskie...) pojawia się na stronie 11, na początku tekstu głównego.

${ }^{3}$ T. Nacher, Dwa dzieła Konarskiego: O religii poczciwych ludzi 1769 i De religione honestorum hominum 1771, Stryj 1883, s. 4 nn.

${ }^{4}$ W. Konopczyński, op. cit., s. 287-297; J. Nowak-Dłużewski, Stanisław Konarski, Warszawa 1989, s. 216-225; T. Chachulski, Stanisław Konarski, Warszawa 2000, s. 62-63.

${ }^{5}$ T. Sinko, Polski Anti-Lukrecjusz, „Rozprawy Akademii Umiejętności. Wydział Filologiczny", Seria 3, 4 [49], Kraków 1911, s. 312-330; W. Wąsik, Historia filozofii polskiej, t. 1: Scholastyka, renesans, oświecenie, Warszawa 1958, s. 240-245; H. Hinz, Deizm, w: Słownik literatury polskiego Oświecenia, red. T. Kostkiewiczowa, Wrocław 1977, s. 70. Z nowszych prac: J. Skoczyński, J. Woleński, Historia filozofii polskiej, Kraków 2010, s. 225. 
uwagę poświęcili Bronisław Treger oraz Martyna Deszczyńska ${ }^{6}$. Można by kontynuować wyliczanie autorów, którzy na przestrzeni ponad 200 lat nawiązywali do tej publikacji, począwszy od pierwszych biografów Stanisława Konarskiego ${ }^{7}$.

We wspomnianych refleksjach dostrzega się (obecne w różnych proporcjach) dwie perspektywy: historyczną oraz filozoficzno-literacką. Pierwsza dotyczy źródłowego ujęcia przebiegu kościelnej dysputy wokół Myśli chrześcijańskich o religii poczciwych ludzi, po tym, gdy nuncjusz Angelo Maria Durini zadenuncjował dzieło pijara jako nieprawowierne, a także związanej z tym problemem kwestii związków między pierwszym wydaniem Myśli chrześcijańskich oraz ich wersją łacińską, De religione honestorum hominum. Druga perspektywa to próby interpretacji dzieła Konarskiego w szerszym kontekście historii idei ${ }^{8}$.

Celem niniejszego artykułu jest przede wszystkim skorygowanie na płaszczyźnie historycznej błędnego sposobu ujmowania następstw oficjalnej denuncjacji, która z nuncjatury warszawskiej wpłynęła do Świętego Oficjum. Pozwalają na to nieznane dotąd historiografii źródła z archiwum Kongregacji Doktryny Wiary w Rzymie, dawnego Świętego Oficjum, którego teologowie na wniosek Duriniego dokonali oceny dzieła polskiego pijara. Źródła te są w istocie dokumentacją procesu, który miał doprowadzić do decyzji, czy zadenuncjowaną książkę umieścić na indeksie ksiąg zakazanych, czy też oczyścić z zarzutów.

Udokumentowana źródłowo korekta faktograficzna zostanie poprzedzona podsumowaniem dorobku interpretacyjnego Myśli chrześcijańskich w dotychczasowej historiografii. Dzięki temu będzie można dostrzec,

${ }^{6}$ B. Treger, Konarski o filozofach, w: Stanisław Konarski pedagog - polityk - filozof, red. J. Ziętarska, Warszawa 2004, s. 95-104; M. Deszczyńska, Polskie kontroświecenie, Warszawa 2011, s. 63-65.

7 „Dzieło jego, O Religii poczciwych ludzi, godne pochwał wielkiego papieża Klemensa XIV, ściga niedowiarstwo obalające święte ustawy panującej religii, nie owym zapalonym duchem, który wzbudzał niegdyś pamiętne rzezią i okrucieństwem wojny, ale jak uczeń słodkiej Chrystusa nauki, łagodnością wyrazów naprowadzając na drogę obłąkane od prawd wiary umysły; jak dobry obywatel zabiegając zepsuciu obyczajów i broniąc upadku cnót obywatelskich” oraz: „Któżby uwierzył, iż to nawet dzieło tak użyteczne Kościołowi, znalazło przeciwników? Konarski osądzony za człowieka mającego wolniejsze zdania i pomówiony o to w Rzymie, broniąc swej niewinności, przełożył tę książkę na łaciński język i samemu Klemensowi XIV wierszem przypisując, podał do roztrząśnienia. Ale czego nienawiść użyć chciała na zawstydzenie jego, to się odmieniło w chwałę", M.D. Krajewski, Pochwała Stanisława Hieronima Konarskiego, Warszawa 1783, s. 79-80, 116.

${ }^{8}$ Wskazać można dodatkowo odniesienia do Myśli chrześcijańskich pojawiające się w pracach z zakresu historii filozofii, np. W. Wąsik, op. cit., s. 240-245; J. Skoczyński, J. Woleński, op. cit., s. 225. 
co w tym dorobku było trafnym, co zaś błędnym domysłem badaczy, niedysponujących pełną podstawą źródłową dla opisania losów książki Konarskiego po jej denuncjacji.

Już Nacher pisał, że dzieło to, „dla celu, w jakim było pisanem, nie było ani ściśle filozoficzną, ani też ściśle teologiczną rozprawą. Polscy Wolterianiści byli to tylko dyletanci, którzy zasmakowali w dowcipnych pismach francuskich filozofów. Konarski chciał tedy również w przystępny sposób wykazać różnicę człowieka poczciwego według pojęć tej nowej filozofii, a poczciwego chrześcijanina"9. Dalej badacz podjął się obrony ortodoksji twórczości religijnej pijara, odpierając zarzuty wielu autorów, głównie Maurycego Dzieduszyckiego, zbyt niewolniczo - jego zdaniem - polegających na sądach Augustina Theinera, który z kolei bezkrytycznie przyjął punkt widzenia Duriniego ${ }^{10}$. Dzieduszycki zarzucał Konarskiemu, że pisał z „ogólnych pozycji chrześcijańskich”, nie zaś katolickich, że na poparcie swych tez cytował autorów przez Kościół potępionych, że błędnie oceniał znaczenie rozumu ludzkiego w relacji do Bożego objawienia, wreszcie, że tym jedynym w całej swej dotychczasowej karierze dziełem poświęconym tematyce ściśle religijnej wywołał w kraju zgorszenie, a jego wersję łacińską - rzekome tłumaczenie, w istocie zaś nową pracę - przygotował, aby oszukać Kurię rzymską i uniknąć skarcenia ${ }^{11}$. Dzięki porównaniu obu wydań Nacher wykazał, że intencją Konarskiego nie było tłumaczenie (Nacher korygował błędną opinię, po raz pierwszy wyrażoną przez Michała Dymitra Krajewskiego w 1783 r.), lecz opracowanie szerszej wersji Myśli chrześcijańskich. Tekst łaciński miał być rodzajem parafrazy, stąd duże różnice

9 T. Nacher, op. cit., s. 3. Autor dodawał: „[Konarski] nie pisał zaś swego dzieła dla rozgłosu w Europie, lub dla pochwały od kuryi, pisał je tylko dla pożytku Polaków, na tle swojskiem, w języku ojczystym", ibidem.

10 Theiner pisał: „Dans un de ses ouvrages (la Religion des honnêtes gens), il renversait toute l'autorité de l'Eglise et tout pouvoir de juridiction du Saint-Siège, et recommandait la tolérance de toutes les sectes religieuses, pourvu qu'elles portassent le nom de chrétiens. Pour complaire à la cour de Russie, il avait demandé, même en 1767, la suppression de la nonciature apostolique, et disait publiquement qu'il ne mourrait pas content jusqu'à ce qu'il n'eût vu ce désir réalisé. Sous sa direction, les collèges de son ordre devinrent en Pologne de véritables pépinières d'impiété, de démoralisation et de corruption", A. Theiner, Histoire du pontificat de Clément XIV, d'après des documents inédits, [traduite de l'allemand sous les yeux de l'auteur par Paul de Geslin], t. 1, Paris 1852, s. 315. Nacher, cytując fragment tego paragrafu dodaje: „Zarzuty te są bardzo ogólne, a ponieważ prócz tego jeszcze i niesłuszne, świadczą, iż ani Durini, ani Theiner (nie znając języka polskiego) tego dziełka sami nie czytali, jeno pisali, co im usłużni przyjaciele nabajali", T. Nacher, op. cit., s. 6.

11 T. Nacher, op. cit., s. 6-12. 
w porównaniu z pierwowzorem ${ }^{12}$. Celem tych wywodów było jednoznaczne stwierdzenie:

Wykazaliśmy tedy wszystkie choćby najmniejsze różnice obu dzieł i przyszliśmy do przekonania, iż dotychczasowe zapatrywania na oba dziełka jako tłumaczenie i oryginał są z gruntu fałszywe. Zasadą główną jest, iż to dziełko późniejsze jest najzupełniej poprawione i przerobione, ale nie możemy przyjąć zdania tego jakoby dopiero łacińskie było katolickiem. Wykazaliśmy bowiem dowodnie, iż dzieło polskie pisane jest ściśle z katolickiego stanowiska, a nadto na chlubę autora trzeba to przyznać, ze stanowiska polskiego patrioty. [--] o dziele łacińskiem nie można tego już wcale powiedzieć. Dzieło przeładowane polemiką zaciekłą, cytatami, pozbawione rysów charakteryzujących je jako polskie, może chyba teologowi sprawić przyjemność dla piękności języka i gorliwości w obronie wiary katolickiej ${ }^{13}$.

Powyższe ustalenia powtórzył Konopczyński, twierdząc, że zaostrzający się konflikt z Durinim skłonił Konarskiego do przygotowania dla papieża szerszej wersji łacińskiej 0 religii poczciwych ludzi, aby oczyścić się z zarzutów stawianych przez nuncjusza. Konopczyński stwierdził, że Święte Oficjum wydało wyrok oczyszczający pijara jeszcze przed wydrukowaniem De religione honestorum hominum ${ }^{14}$.

W istocie zarówno Dzieduszycki, jak i Nacher oraz Konopczyński mylili się co do genezy łacińskiego wydania pracy Konarskiego, o czym będzie mowa w ostatnich paragrafach niniejszego artykułu.

Wracając do płaszczyzny interpretacyjnej, trzeba stwierdzić, że Nacher skoncentrował się na wykazaniu katolickiej prawowierności Myśli chrześcijańskich, wbrew zarzutom, iż jest to dzieło promujące indyferentyzm wyznaniowy czy nawet zawoalowaną formę deizmu, a w kwestiach kościelnych febronianizm. Konopczyński przestrzeń interpretacji znacznie poszerzył, streszczając pokrótce główne tezy pijarskiego reformatora, a z niektórymi polemizując ${ }^{15}$. Wydaje się, iż krakowski profesor

12 Ibidem, s. 19-20. Nacher wskazał na różnice trojakiego rodzaju: 1) tekst łaciński zawiera fragmenty, których brak w wydaniu polskim; 2) wiele zdań z pierwszego wydania przetłumaczono dość swobodnie; 3) niektóre zdania obecne w wersji polskiej zostały pominięte w wydaniu łacińskim.

13 Ibidem, s. 34.

${ }^{14}$ W. Konopczyński, op. cit., s. 297. Podobną wersję wydarzeń przytaczają opracowania najnowsze, zob. np. J. Skoczyński, J. Woleński, op. cit., s. 225 - jest to praca opublikowana w $2010 \mathrm{r}$.

${ }^{15} \mathrm{~W}$ komentarzu do surowego osądu moralności starożytnych filozofów Konopczyński pisze: „Skąd mu na to przyszło? Co zależało Konarskiemu na takiem obniżaniu w oczach uczniów - bo dla nich przede wszystkiem tę książkę pisał - klasycznych 
zastanawiał się przede wszystkim, jak pogodzić spuściznę piśmienniczą Konarskiego „postępowca” z niektórymi stwierdzeniami omawianego dzieła, które kontrastowały z oświeceniowym zaufaniem do ludzkiego rozumu jako skutecznego narzędzia w pracy nad ulepszaniem społeczeństwa. Dlatego konkludował: „Kto chce stwierdzić, że ks. Stanisław nie zaprzeczył sobie, jako pionier Oświecenia właśnie w dziedzinie religijnej, ten niech przeczyta przypis do rozdziału VII, a w nim takie zdania: «bez konsensu rozumu i sama religia być u nas nie może», «kto rozum poniża [--] musi zawsze wielkim zapieczętować głupstwem»"16.

Genezy dzieła Konopczyński upatrywał w uważnym oglądzie zmieniającej się rzeczywistości politycznej w Europie: „Wygodna filozofia zawładnęła teraz na dworach, jej hołdowali Fryderyk, Katarzyna, Józef, oraz ich «oświeceni» ministrowie: Hertzbergi, Paniny, Kaunitze, zaś wielki Dalaj-Lama opinii salonowej, Wolter, płaszczył się przed cynizmem i obłudą despotów-filozofów z bluźnierczym okrzykiem: Te Catharinam laudamus!"17. Katoliccy władcy celowali w antykościelnych posunięciach, „a głębiej myślących ogarniała trwoga o całą przyszłość religii i etyki chrześcijańskiej. Wtedy Konarski z właściwą sobie szczerością spróbował położyć kojącą rękę na ropiejącej ranie religijnej społeczeństwa"18.

przykładów mądrości i cnoty, do których i sam w dawniejszych pismach nieraz się odwoływał? Czyżby to była reakcja, zwrot wsteczny w duszy żałującego postępowca, może pod wpływem przeczuwanej śmierci?”. I dalej: „Nie jest rzeczą historyka spierać się o przekonania z autorem, którego życiorys przedstawia; sądzimy, że po Emanuelu Kancie, rzadko kto nawet z ludzi wierzących pójdzie za tezą §5, a i niezależnie od dogmatów etycznych trzeba przyznać, że nasz pijar pomieszał wewnętrzną szlachetność jednostki z tężyzną sił moralnych wyrabiających się historycznie: można było twierdzić na mocnej podstawie, że bez wychowawczego wpływu Kościoła i jego nauki ludzkość nie doszłaby do takiego stadium, w którem znaczna liczba ludzi wstrzymywałaby się od zbrodni w życiu prywatnym po prostu przez brak złych skłonności, bez oglądania się na zagrobowe kary, - a jednak można było nie oskarżać w czambuł «poczciwych ludzi», że gonią tylko za korzyścią doczesną lub punktem honoru”, W. Konopczyński, op. cit., s. $288,290$.

16 Ibidem, s. 290-291.

17 Ibidem, s. 287.

${ }^{18}$ Konopczyński dodawał niżej: „Że Konarski z mniejszem zaufaniem patrzał na niechrześcijańską filozofię w r. 1768, niż przed kilkudziesięciu laty, kiedy to nawet jmp. Woltera jako «wiatyk» zalecał, to nie ulega wątpliwości. Przez tych lat 40, które napełnił walką o oświatę nowożytną z obskurantyzmem, ściągając na siebie niezliczone groty wsteczników, wolna myśl zachodnio-europejska okazała jaskrawą antykościelną tendencję [--]. Czas było przeprowadzić linię demarkacyjną między ich filozofią, dochodzącą do zaprzeczania wolnej woli i odpowiedzialności moralnej człowieka, a sposobem myślenia «Szkół Pobożnych», i takie właśnie oświadczenie: «dotąd, ale nie dalej», składa w swej książce Konarski”, ibidem, s. 288-289. 
Podobną motywację leżącą u podstaw Myśli chrześcijańskich dostrzegał także Nowak-Dłużewski, lecz spoglądał na dzieło w szerszym kontekście. Podobnie jak Konopczyński podkreślił ewolucję poglądów Konarskiego, wynikającą z radykalizacji środowiska francuskich filozofów w kwestiach światopoglądowych i uznał, że polemiczne dzieło pijara nie stanowiło jakiegoś „załamania dotychczasowej jego linii życiowej”19. Krytyczna ocena społeczeństwa, które pozbawiłoby się fundamentu etyki chrześcijańskiej i uległo czarowi filozofii „poczciwych ludzi”, kiełkowała w pracach pijara znacznie wcześniej: „pierwszy raz wystąpił przeciw «ludziom poczciwym» w Mowie o kształtowaniu człowieka poczciwego i dobrego obywatela - i odtąd przez całe piętnaście lat nie pomija żadnej sposobności w obronie sprawy, którą uważał za słuszną"20.

Nowak-Dłużewski umieścił zatem etyczne refleksje Konarskiego w kontekście jego wcześniejszej „antydeistycznej akcji” oraz narastającej w polskiej literaturze krytyki „poczciwych ludzi”, ale przede wszystkim wskazał na istotną tezę pijara o tożsamości idei reformy Rzeczypospolitej oraz chrześcijańskiego fundamentu cnót obywatelskich:

Poznajemy w Konarskim rezonera, który tym samym orężem, powoływaniem się na ludzką naturę, obalał bałwana liberum veto w Skutecznym rad sposobie. Nie byłby Konarski sobą, gdyby i w tej rozprawie [Myślach chrześcijańskich] zapomniał o własnym narodzie. Abstrakcyjny „naród ludzki” nie przemawia mu do przekonania. Z rozprzężenia moralnego (rzekomego czy rzeczywistego, w to nie wchodzimy), które grozi społeczeństwu polskiemu przy praktykowaniu etyki „ludzi poczciwych" wyciąga wnioski natychmiastowe. „Decydowana więc rzecz: albo zginąć nam i przestać tym, cośmy byli narodem potrzeba, albo obyczaje odmienić". Gotów jest teraz zaprzeczyć swojej tezie generalnej Skutecznego rad sposobu, że całe zbawienie kraju, łącznie z religią i etyką chrześcijańską, zależy od naprawy „rady”. W Religii poczciwych ludzi dochodzi do innego wniosku. „Dobrze to tedy mówią, że nas wprzód samych, niżeli rząd, odmienić i przelać trzeba". Inny w tym dziele zakłada łańcuch przyczynowy [--]. „Bez dobrych obyczajów nie uda się poprawić Rzeczypospolitej, a że cnota, poczciwość i dobre obyczaje w narodzie być nie mogą bez religii, więc najskuteczniej do ubezpieczenia onej przeciw szkodliwym nowościom dopomóc raczy". To król, do którego o sankcje zwraca się Konarski przeciw importowi do Polski „bezbożnych druków”21.

${ }_{19}$ Zob. J. Nowak-Dłużewski, op. cit., s. 216. Pisał o tym i Konopczyński, op. cit., s. 288 .

20 J. Nowak-Dłużewski, op. cit., s. 221.

${ }^{21}$ Ibidem, s. 218. Por. J. Łukowski, Od Konarskiego do Kołtataja - czyli od realizmu do utopii, w: Trudne stulecia. Studia z dziejów XVII i XVIII wieku. Ofiarowane profesorowi Jerzemu Michalskiemu $w$ siedemdziesiątą rocznicę urodzin, red. Ł. Kądziela, W. Kriegseisen, 
Nowak-Dłużewski przypomniał za Sinką o zależności między Myślami chrześcijańskimi a Niewiara zwalczana samym zdrowym rozsądkiem Stanisława Leszczyńskiego ${ }^{22}$. Sinko w Polskim anti-Lukrecjuszu szerzej omówił antydeistyczną polemikę kardynała Melchiora de Polignaca ${ }^{23}$, Stanisława Leszczyńskiego ${ }^{24}$ i Stanisława Konarskiego ${ }^{25}$. Dopiero z takiej perspektywy wyraźnie widać także pewne ograniczenia Myśli chrześcijańskich jako oręża polemicznego w osiemnastowiecznej konfrontacji światopoglądowej:

Konarski nie dał w swych Myślach chrześcijańskich kompletnej apologii chrześcijaństwa, a przynajmniej etyki chrześcijańskiej wobec napaści deistów, głoszących nową etykę „naturalną” czy „racjonalną”, jak Leszczyński nie przeprowadził systematycznej kampanii przeciw niedowiarstwu i ateizmowi: obaj poprzestali na okolicznościowych polemikach, operując tylko częścią możliwych argumentów i to wyłącznie rozumowych, racjonalistycznych argumentów. Ale od okolicznościowych broszur trudno było wymagać więcej, jak zebrania bieżących oklepanek, puszczanych w kurs przez wszystkich adwersarzy ateistów, a po części i deistów. Nie można przykładać do nich tej samej miary, co do dzieła połowy żywota Polignaca. To jest uczona księga filozoficzna, tamto popularyzujące artykuły. Nowym Polignakiem chciał być dopiero Ignacy Wilczek ${ }^{26}$, który przynajmniej dziesięć lat pracy poświęcił na napisanie i wygładzenie poematu przeciw tym samym wrogom ${ }^{27}$.

Z. Zielińska, Warszawa 1994, s. 184-194. Jak wykazał Łukowski, chrześcijański realizm w spojrzeniu na człowieka był dla Konarskiego jednym ze źródeł jego idei reformy politycznej Rzeczypospolitej. „Ludzie - czy to jednostki, czy zgromadzenia - byli mieszaniną dobrego i złego: tak zawsze było i tak zawsze zostanie. [--] Wszak między Chrystusem a apostołami powstały nieporozumienia. Wychowanie ludzi było możliwe, ale odmiana natury ludzkiej przekraczała możliwości; taka reforma należała do Boga i do religii, a nie do żadnych urządzeń", J. Łukowski, op. cit., s. 90, 91.

${ }^{22}$ J. Nowak-Dłużewski, op. cit., s. 219. Dodawał: „Praca Konarskiego ustępuje pracy Leszczyńskiego, wykonanej w sposób teoretycznie doskonalszy, tak jak obie muszą ustąpić pracy Francuza Polignaca, autora traktatu antydeistycznego na wysokim poziomie filozoficznym", ibidem, s. 220.

${ }^{23}$ Zawartą w pośmiertnie wydanym dziele M. de Polignac, Anti-Lucretius, sive de Deo et natura, t. 1-2, Paris 1745. Tłumaczenie francuskie ukazało się cztery lata później: Anti-Lucrèce, poème sur la religion naturelle, tłum. J.-P. de Bougainville, Paris 1749.

${ }^{24}$ S. Leszczyński, Le philosophe chrétien, [b.m.] 1749; idem, L'incrédulité combattue par le simple bon sens, Nancy 1760; idem, Des désirs, w: Ouvres du philosophe Bienfaisant, t. 1, Paris 1763, s. 306-325; idem, La Religion [b.m., b.d.], w: Ouvres du philosophe Bienfaisant, t. 4, Paris 1763 , s. $171-186$.

${ }^{25}$ T. Sinko, op. cit. s. 312-330.

${ }^{26}$ I. Wilczek, Carmina. Nova Editio Altera Sui Parte Auctior Et Emendatior, Calissii 1785. Część tego dzieła autor opublikował już w 1777 r. Poszczególne wersje kolejnych wydań różnią się kompozycją. Sinko stwierdził: „Kto by miał w ręce wszystkie wydania, mógłby 
Sinko dość obszernie streścił pracę Leszczyńskiego L'incrédulité combattue par le simple bon sens, ale w niej także dostrzegł usterki: „brak zwartej kompozycji, przeskakiwanie z tematu na temat, słowem ogromną pobieżność roboty"28; wskazał ponadto na refleksję nad deizmem obecną w innych pracach księcia Lotaryngii. Dzieło Konarskiego uznał za wtórne wobec intuicji Leszczyńskiego, które pijar znać musiał. Myśli chrześcijańskie uznał za zbudowane wokół idei zawartych „w drugiej części Filozofa chrześcijańskiego" ${ }^{29}$, choć z innym zamierzeniem: ,jeśli u Leszczyńskiego polemika $\mathrm{z}$ ateizmem i deizmem miała znaczenie raczej teoretyczne, to Konarski prowadzi ją wyłącznie z pobudek praktycznych, a te łączą się z wielkim dziełem reformy państwa. [--] Taki cel broszury Konarskiego pociągnął za sobą pewne obniżenie poziomu polemicznego"30. Ów niższy poziom dostrzec można było - zdaniem krytyków - już na pierwszych stronach rozprawy, poświęconych źródłom deistycznego credo. Nadmiernie negatywną ocenę filozofów starożytnych jako nauczycieli osiemnastowiecznych „poczciwych ludzi” Sinko uznał za „,niezbyt potrzebny do walki z deistami antyhumanistyczny ekskurs" ${ }^{31}$. Jak wskazano wyżej, wątek ów budził także zdumienie Konopczyńskiego, a Treger poświęcił mu cały artykuł, w którym słabość argumentacji Konarskiego przeciw antycznym mędrcom uznał za mało chlubny wyjątek w dorobku człowieka zasłużonego „dla rozwoju wielu dziedzin kultury politycznej i intelektualnej" i za rodzaj chwilowej słabości, której ulec może nawet jednostka wybitna ${ }^{32}$.

napisać o tem ciekawe studium bibliograficzne", T. Sinko, op. cit., s. 317. To właśnie dzieło nazywał Sinko polskim Anti-Lukrecjuszem, dodając: „Łacińskie pieśni Wilczka były nie literacką zabawką, lecz aktualnymi broszurami, skierowanymi przeciw ruchowi deistycznemu i ateistycznemu w Polsce. Początki tego ruchu i jego źródła poznaliśmy powyżej z ech zawartych w Sarmatides A. Ponińskiego", T. Sinko, op. cit., s. 318.

${ }_{27}$ T. Sinko, op. cit., s. 330.

${ }^{28}$ Ibidem, s. 318.

${ }^{29}$ Ibidem, s. 325. Juliusz Nowak-Dłużewski, powołując się na Sinkę, twierdzi, że filolog klasyczny udowodnił zależność Myśli chrześcijańskich od Niewiary zwalczanej samym zdrowym rozsądkiem, co powtórzył za nim także B. Treger, op. cit., s. 102.

${ }^{30}$ T. Sinko, op. cit., s. 325. Nowak-Dłużewski ze swej strony twierdził, że „Religia poczciwych ludzi przy całej kulturze metodycznej, której dowody złożył Konarski i w innych pismach, wykazuje braki konstrukcyjne, które jej odbierają wartość zharmonizowanego w sobie poglądu filozoficznego. [--] Trzeba więc zgodzić się ze zdaniem badaczy Konarskiego, którzy twierdzą, że pijar nie był umysłem spekulatywnym", J. Nowak-Dłużewski, op. cit., s. 220.

31 T. Sinko, op. cit., s. 326.

32 Treger pytał o „przyczynę tak wyraźnego zwrotu w opiniach o filozofii i filozofach dającego się zaobserwować w licznych partiach Filozofii chrześcijańskiej [Samuela Chróścikowskiego] i w dziele 0 religii poczciwych ludzi”. Jego hipoteza sugeruje, iż 
Czy negatywne i uproszczone potraktowanie filozofów antycznych mogło być związane z zamierzonym przez autora charakterem „praktycznym” jego dzieła? Choć Deszczyńska podkreśliła, iż Konarski „przestrzegał, by uniknąć zbagatelizowania lub wyśmiania, że jego słowa «to nie $\mathrm{z}$ ambony na poczciwych ludzi satyra, nie inwektywy księże»", sama uznała pracę pijara za „dziełko dydaktyczno-religijne”"33. Sinko był zdaje się tego samego zdania, pisząc: „Słusznie przypuszcza Konarski (w §9), że uwagi jego o wpływie złych obyczajów na upadek państw mogą się komuś zdać «pustelniczymi, nie polityków refleksjami». Sąd ten można rozciągnąć i na resztę Myśli chrześsijańskich, które, wierne swemu tytułowi, mają charakter raczej kaznodziejski niż filozoficzny"34. Być może taka właśnie była intencja Konarskiego - bezkompromisowe, w duchu „kaznodziejskim” odrzucenie najpiękniejszych nawet idei, które nie posiadały wewnętrznej siły obligowania swych wyznawców do prawdziwie moralnego życia.

Myśli chrześcijańskie streszczano przynajmniej kilkakrotnie, także w wyżej wymienionych publikacjach. Sinko jako pierwszy zwięźle ujął główne punkty polemiki Konarskiego: pogańscy filozofowie dali przykład niemoralnego życia przystrojonego w piękne frazesy. Idąc za ich przykładem, współcześni deiści troszczą się tylko o pozór cnót (odrzucają cnoty chrześcijańskie: wiarę, nadzieję, miłość, bojaźń Bożą, pokutę, pokorę $\mathrm{i}$ in.), a ich postępowanie jest nieszczere - choć z uwagi na opinię ludzką wydaje się być prawe, w swej istocie jest często niemoralne i oparte na pobudkach egoistycznych. Cnota pozbawiona nadziei nagrody wiecznej traci swój najgłębszy sens i nie daje szczęścia w życiu doczesnym, prowadząc do hipokryzji. Rezygnacja z treści wiary objawionej przez Boga prowadzi do negacji podstawowych zasad życia religijnego oraz rodzi postawy antykościelne i antychrześcijańskie (,w ewangelii widzą jedynie kodeks moralności, a odrzucają tajemnice, sakramenta, ceremonie, gardzą hierarchią kościelną i naśmiewają się z duchowieństwa [--], a całą religię, jej tajemnice i praktyki, modlitwy i cnoty chrześcijańskie «za superstycyję i fanatyzm poczytują i głoszą»"35). Poczciwy chrześcijanin

\footnotetext{
„Konarski zląkł się, że antypijarska propaganda w jakiejś mierze poskutkuje i wpłynie na ograniczenie naboru do konwiktów. Postanowił więc za wszelką cenę udowodnić prawomyślność swą jak również współpracujących z nim konfratrów, prawomyślność będącą przecież gwarancją odpowiedniego formowania konwiktorów", B. Treger, op. cit., s. 104.

${ }^{33}$ M. Deszczyńska, op. cit., s. 64, 65. Zacytowany fragment pochodzi z Myśli chrześcijańskich o religii poczciwych ludzi, Warszawa 1769, s. 68.

34 T. Sinko, op. cit., s. 327.

35 Parafraza słów Konarskiego zapisanych na s. 110 Myśli chrześcijańskich (wydanie z 1769 r.), T. Sinko, op. cit., s. 327.
} 
przewyższa pod każdym względem „poczciwego człowieka”, ponieważ jego postępowanie, oparte na mocnych i obiektywnych fundamentach, lepiej służy dobru społecznemu („zepsucie obyczajów gubi narody”), a w wymiarze indywidualnym zapewnia poczucie szczęścia w życiu doczesnym i gwarantuje szczęśliwość wiecznąą ${ }^{36}$ Sinko nieco lepszą argumentację na poziomie filozoficznym dostrzega w Konarskiego obronie konieczności przyjęcia Bożego objawienia dla sformułowania poprawnej teologii oraz niesprzeczności tego faktu z godnością rozumu ludzkiego, w jego polemice z Pierre'em Bayle'm, twierdzącym „iż «ateistowie mogą być bardzo szczęśliwi» i że «naród z samych ateistów złożony, mógłby być szczęśliwy»", wreszcie w jego refleksji nad chrześcijańską pokorą, która nie przeszkadza w twórczym życiu ${ }^{37}$.

Podobnie zwięzłe streszczenie zawarł w swej biografii Konopczyński, zestawiając czasem zarzuty Konarskiego z intuicjami Immanuela Kanta, a tym samym broniąc idei „moralności niezależnej” przeciw radykalnym stwierdzeniom pijara $^{38}$. Nowak-Dłużewski obok wspomnianych już punktów przypomniał te fragmenty Myśli chrześcijańskich, w których autor uznawał pozytywne aspekty niechrześcijańskiej filozofii oraz krytykował zabobon, niewykształcenie, bigoterię i hipokryzję niektórych chrześcijan ${ }^{39}$. Wąsik także na to zwrócił uwagę: „Konarski zwalczał więc zarówno irreligijność, jak i bigoterię, pogrążenie się w formalizmie religijnym albo raczej w zewnętrznych pozorach nabożności, a zalecał zachowanie złotego środka pomiędzy tymi skrajnościami" ${ }^{40}$. Treść Myśli chrześcijańskich Wąsik podzielił na wątki związane z definicją deizmu (nieprecyzyjną u Konarskiego) oraz refleksje etyczne, podkreślił też dość liberalne stanowisko pijara w kwestii wolności sumienia, brak polemiki z innymi wyznaniami chrześcijańskimi czy religiami niechrześcijańskimi ${ }^{41}$. Ocena pracy Konarskiego zaprezentowana przez Wąsika była entuzjastyczna:

${ }^{36}$ Ibidem, s. 326-328.

37 Ibidem, s. 328-330.

38 W. Konopczyński, op. cit., s. 287-291, zwł. s. 289.

39 J. Nowak-Dłużewski, op. cit., s. 219.

${ }^{40}$ W. Wąsik, op. cit., s. 244.

${ }^{41}$ Ibidem, s. 241-244. W świetle krytycznych uwag na temat Myśli chrześcijańskich wyrażonych przez cytowanych wyżej Sinkę czy Nowaka-Dłużewskiego, Treger (op. cit., s. 101-102) krytycznie ocenił zdanie Wąsika o dziele pijara, które miałoby stanowić „najznakomitsze, a może i najbardziej oryginalne pismo polskiej doby Oświecenia dotyczące religii naturalnej, w którym autor rozpatrzył krytycznie deizm ze stanowiska religii chrześcijańskiej w duchu na swój czas postępowym", W. Wąsik, op. cit., s. 241. 
Najważniejszym wnioskiem, do którego dochodzi autor, jest to, że Bóg dał człowiekowi „co do życia doczesnego... rozum, co zaś do drugiego, przyszłego, w wieczności należy życia, dał człowiekowi rewelacyją". Sam więc rozum wystarcza, by pod jego kierownictwem dobrze żyć tu na ziemi, ale jest on niedostateczny, by mógł zapewnić człowiekowi zbawienie: do tego potrzebne jest koniecznie objawienie. Postawa Konarskiego wobec tego zagadnienia jest wyraźnie kompromisowa, zmierza do pogodzenia rozumu $\mathrm{z}$ rewelacją, a raczej wyznacza zakres ich kompetencji ${ }^{42}$.

W takim ujęciu słabnie nieco pojmowanie Myśli chrześcijańskich jako dzieła wybitnie polemicznego, a autor tej opinii zdaje się nawet rozumieć zasadność kontrowersji, które wzbudziło one w kręgach katolickich hierarchów ${ }^{43}$. Przeciwne stanowisko zajęła w tej kwestii Deszczyńska, omawiając pracę Konarskiego w szerokim kontekście polskiego piśmiennictwa podejmującego się „krytyki «światopoglądów» oświecenia”. W jej ujęciu nie ma mowy o pojednawczym tonie Konarskiego, a streszczając Myśli chrześcijańskie uwypukla ich polemiczny charakter, z jednoznacznie negatywną oceną hipokryzji filozofów, którzy, pozorując cnotę i dobre obyczaje, w istocie prowadzą do zniszczenia kraju i społeczeństwa ${ }^{44}$.

Pomimo tak bogatej dyskusji oraz licznych refleksji, do których dzieło Stanisława Konarskiego pobudzało badaczy, kwestia jego genezy pozostaje wciąż aktualnym problemem badawczym. Przy braku pozytywnych świadectw źródłowych wypada odrzucić hipotezę o Myślach chrześcijańskich jako apologii własnej ortodoksyjności pijara, wobec narastającej fali krytyki kolegiów pijarskich, obliczonej na doraźne skutki. Jerzy Łukowski, opisując światopogląd Konarskiego, podkreślał „chrześcijański humanizm” oraz ,język historii i doświadczenia” obecny w całej jego twórczości: „Mimo obeznania z nową filozofią, Konarski zachowywał wobec niej wielką ostrożność. Nie kwestionował roli czy doktryn Kościoła katolickiego" ${ }^{45}$. W artykule Łukowskiego tytułowy „realizm” pijara $\mathrm{w}$ parze $\mathrm{z}$ chrześcijańskim humanizmem mógł być podstawą wystarczającą do zabrania głosu w sporze światopoglądowym. Filozofia „poczciwych ludzi” przynosiła na oczach Konarskiego konkretne i niepokojące efekty polityczne, o czym pisał Konopczyński. Pijar mógł

42 W. Wąsik, op. cit., s. 243.

43 „Wydaje się, że ustępstwa na rzecz deizmu u Konarskiego są najdalsze, na jakie można było sobie pozwolić przy zachowaniu prawowierności, a może nawet z punktu widzenia ortodoksji za wielkie", ibidem, s. 244.

${ }^{44}$ M. Deszczyńska, op. cit., s. 64 (całość refleksji nad dziełem Konarskiego zob. s. 63-65; rozdział „Krytyka «światopoglądów» oświecenia”, s. 57-84).

${ }^{45} \mathrm{~J}$. Łukowski, op. cit., s. 185, 187. 
przewidywać, iż losy dyskusji z deistami (w jego szerokim rozumieniu tego terminu, oznaczającego także ludzi bezbożnych, libertynów, filozofów, „fundatorów religii i reformatorów państw i rządów”46), bez oparcia jej na fundamentach objawienia chrześcijańskiego, były przesądzone, co zresztą widać na przykładzie niektórych „antyfilozoficznych” polemik toczonych w Europie drugiej połowy XVIII w.

Przegląd interpretacji książki Konarskiego wskazuje, że z niewielkimi wyjątkami (Dzieduszycki, podążający za Theinerem) polscy badacze nie dostrzegali w niej podstaw do oskarżenia o nieprawowierność z perspektywy nauczania Kościoła katolickiego. Wysunięcie takiego zarzutu przez Duriniego postrzegali w kontekście szerszego konfliktu nuncjusza z pijarem. Koncentrowali się też na ocenie wartości polemiki Konarskiego z deizmem, dostrzegając zarówno braki argumentacji, jak i ciągłość w myśli pijara, stojącego w całej swej twórczości na gruncie światopoglądu chrześcijańskiego. Żadna z tych refleksji nie pozwala na przesądzenie kwestii genezy dzieła, a tym bardziej nie daje odpowiedzi na pytanie o następstwa wysuniętego przez nuncjusza oskarżenia o niekatolickie treści.

W tym miejscu powrócić trzeba do problemu oceny Myśli chrześcijańskich przez teologów Kurii Rzymskiej. Dochodzenie, które na przełomie 1769 i 1770 r. przeprowadzono w Rzymie nad ostatnim dziełem Konarskiego, będzie przedmiotem osobnego szczegółowego studium oraz projektu edytorskiego. Poniżej zostaną jedynie podsumowane najważniejsze fakty związane z rzymskim procesem, który odbył się zgodnie z zasadami obowiązującymi w Kurii Rzymskiej.

Angelo Maria Durini zadenuncjował nieprawowierność dzieła Konarskiego w piśmie z 23 czerwca 1769 r., adresowanym do rzymskiej Kongregacji Świętego Oficjum (dziś Kongregacji Doktryny Wiary) ${ }^{47}$. Nuncjusz pisał:

W styczniu ukazała się tutaj książeczka w języku polskim zatytułowana O religii poczciwych ludzi, dzieło ojca Stanisława Konarskiego, pijara. Natychmiast zaczęto o niej mówić, zarówno pozytywnie, jak i krytycznie; głosy pozytywne podkreślały, że nie można było lepiej odeprzeć deizmu; bardziej roztropni podkreślali jednak, że autor nie skorzystał z argumentacji opartej na zasadach wiary rzymskokatolickiej, a odwołując się wyłącznie do ogólnych zasad chrześcijańskich propagował tolerantyzm bądź indyferentyzm. $\mathrm{Z}$ tego powodu uznałem za obowiązek wynikający z mego urzędu przekazać tę książkę teologom z trzech różnych zakonów do analizy, a ich opinie przesyłam niniejszym Waszym Ekscelencjom, razem z egzemplarzem książki.

${ }^{46}$ W. Wąsik, op. cit., s. 241.

47 A.M. Durini do Kardynałów Św. Oficjum, 23 VI 1769, Archivum Congregationis Doctrinae Fidei (dalej: ACDF), Censurae Librorum (dalej: C.L.) 1770 (N. 5), fol. 101r.-v. 
O. Konarski jest człowiekiem światłym, ale słyszę, że ma braki w zakresie teologii i prawa kanonicznego; uznaje się go za zwolennika i stronnika polityki rosyjskiej, którą zamierzano przyjąć na ostatnim sejmie. Żywiłem dlań sympatię z uwagi na jego twórczość literacką, ale po opublikowaniu tego [ostatniego] dzieła nie zadałem sobie więcej trudu, by go widywać. Jeśli opinie [teologów] są prawdziwe, z pewnością zasługuje na siarczyste potępienie Waszych Ekscelencji, którym składam wyrazy pokornego szacunku ${ }^{48}$.

Tego rodzaju denuncjacja zainicjowała formalny proces, który mógł się zakończyć umieszczeniem nieprawowiernej pracy na indeksie ksiąg zakazanych. Kompetentne w tej materii były dwie kongregacje - Świętego Oficjum oraz Indeksu. Ta druga dysponowała jednak mniejszym personelem i obradowała rzadziej, choć ostatecznie to ona opracowywała kolejne wersje książkowe Indeksu. Pierwszej przypadały w udziale sprawy poważniejsze, a za taką z pewnością uznano oskarżenie jednego z najbardziej znanych w Polsce autorów, należącego do grona osób bliskich królowi. Ponadto struktura Świętego Oficjum umożliwiała lepszą realizację zasad procesowych, zreformowanych przez Benedykta XIV w konstytucji Sollicita ac provida z 9 lipca 1753 r. Do tych zasad należała m.in. troska o życzliwe nastawienie do autora, zwłaszcza katolickiego, o nieposzlakowanej dotąd reputacji. Przypadki dwóch możliwych interpretacji jego zdania - ortodoksyjnego i heretyckiego - należało rozstrzygać na korzyść interpretacji ortodoksyjnej. Wymagało to szczegółowej analizy badanego dzieła przez kompetentnych konsultorów ${ }^{49}$.

48 „Fin dallo scorso gennaro comparve al pubblico un libretto in lingua polacca intitolato Della Religione degli uomini onesti, opera del Padre Stanislao Konarski delle Scuole Pie. Cominciossi subito a parlarne da chi in lode, e da chi in biasimo; in lode si diceva, che meglio non potevasi combattere il deismo; i più avveduti però rilevavano, che non servendosi l'autore di argomenti tratti dai fondamenti, ed articoli della fede Romano-Cattolica, ma dalla sola Cristiana in genere, pareva indurre il tolerantismo, o sia indifferentismo. Per lo che sembrommi atto indispensabile del mio ministero darlo alla disamina di valenti teologi di tre diversi ordini, le di cui censura umilio qui all'EE. VV. unitamente al sud[ett]o libretto. Il P. Konarski è uomo letterato, ma sento sia molto scarso di teologia, e di ius canonico; passa per cortiggiano, e fautore del sistema Russo, che si voleva stabilire nell'ultima Dieta. Io lo trattavo con piacere per la sua letteratura, ma dopo avere egli stampata quest'opera, non mi son curato più di vederlo. Se le censure dicono vero, merita certamente una sonora condanna dell'EE. VV., alle quali intanto fo umilissima riverenza", ibidem. Tłum. włoskich i łacińskich cytatów - P.Z.

${ }^{49} \mathrm{Na}$ temat procedur kwalifikowania (bądź nie) danej książki do indeksu ksiąg zakazanych oraz samego procesu, H. Wolf, Storia dell'Indice. Il Vaticano e i libri proibiti, Roma 2006, s. 25-38; H. Wolf, B. Schmidt, Benedikt XIV und die Reform des Buchzensurverfahrens. Zu Geschichte und Rezeption von „Sollicita ac provida”, Paderborn 2011 (wraz z transkrypcją konstytucji). O właściwym interpretowaniu dwuznacznie brzmiących 
Do oceny książki Konarskiego wyznaczono dwóch konsultorów: pomocniczego Serafina Maccarinellego OP oraz głównego, arcybiskupa Giorgia Marię Lascarisa (teatyna). Lascaris miał od dawna bliskie związki z Rzecząpospolitą - w 1738 r. był prefektem teatynów we Lwowie, rezydował u Radziwiłłów w Nieświeżu, święcenia biskupie przyjął w kolegiacie ołyckiej, angażował się w reformę Akademii Zamoyskiej, posiadał beneficja we Lwowie, Żółkwi i Ołyce. W czasie konfederacji barskiej „uważał, że nie należy drażnić Rosji, która zajęta wojną z Turcją będzie skłonna do ustępstw w zakresie wyznaniowym na terenie polskim. Skłaniał papieża do milczenia wobec apelu konfederatów"50.

Na przełomie 1769 i 1770 r. Lascaris zlecił przygotowanie włoskiego i częściowo łacińskiego tłumaczenia pracy Konarskiego, aby lepiej odpowiedzieć na zarzuty polskich teologów - niestety anonimowych (ich nazwiska pozostają do ustalenia) - których opinie także miał do dyspozycji. Tłumaczenie to zostało wykonane w częściach przez różnych autorów, aby zaoszczędzić na czasie ${ }^{51}$. Musiało być gotowe w pierwszych miesiącach 1770 r., ponieważ już pod koniec marca jeden z rzymskich teologów, Bartolomeo Carrara, przekazał Lascarisowi własne uwagi na temat dzieła Konarskiego, odrzucając zdecydowanie oskarżenia polskich teologów, których opinie przesłał do Rzymu nuncjusz Durini ${ }^{52}$.

Wiosną 1770 r. Lascaris opracował szczegółową analizę dzieła Konarskiego, odnosząc się precyzyjnie do krytycznych spostrzeżeń nadesłanych z Warszawy, oraz sformułował opinię o poszczególnych kwestiach wątpliwych, którą podpisał także Maccarinelli53. Opinia Lascarisa zmierzała do oczyszczenia Konarskiego ze stawianych mu w Polsce zarzutów, nie ukrywała jednak dwuznaczności pewnych sformułowań Myśli chrześcijańskich. Nad tym obszernym elaboratem dyskutowali następnie

zdań mówi punkt 19 konstytucji Sollicita ac provida: „Quod si ambigua quaedam exciderint auctori, qui alioquin catholicus sit, et integra religionis doctrinaeque fama, aequitas ipsa postulare videtur, ut eius dicta benigne, quantum licuerit, explicata, in bonam partem accipiantur", H. Wolf, B. Schmidt, op. cit., s. 148.

${ }^{50}$ F. Stopniak, Laskarys (Lascaris) Jerzy Hieronim Maria Wojciech (1706-1795), PSB, t. 16, Wrocław-Warszawa-Kraków 1971, s. 519. Nowe ustalenia na temat Lascarisa i jego związków z Polską J. Pietrzak, Testament patriarchy jerozolimskiego Jerzego Marii Laskarysa ze zbiorów Archiwum Zamku Królewskiego w Warszawie-Muzeum, „Kronika Zamkowa. Roczniki" 2015, 2 (68), s. 297-343.

${ }^{51}$ Della religione degli uomini onesti di Stanislao Kona[r]ski delle Scuole Pie [rkp.], ACDF, C.L. 1770 (N. 5), fol. 153r.-238v.

52 B. Carrara do J.M. Lascarisa, 24 III 1770, ACDF, Vota C.L. 1757-1809, 74-83 [4], brak fol.

${ }^{53}$ J.M. Lascaris, [Opinia, incipit: Essendo uscito alla luce...], ACDF, C.L. 1770 (N. 5), fol. $104 \mathrm{r} .-128 \mathrm{v}$. 
konsultorzy Kongregacji. Na przełomie czerwca i lipca 1770 r. zlecili Lascarisowi i Maccarinellemu przygotowanie wskazówek dla Konarskiego co do niezbędnych poprawek ${ }^{54}$.

Ostateczna decyzja w sprawie książki Konarskiego w Kongregacji Świętego Oficjum zapadła 19 lipca 1770 r., a więc ponad rok od denuncjacji Duriniego, podczas posiedzenia kardynałów Kongregacji, w obecności papieża Klemensa XIV. Werdykt brzmiał: „Dzieła należy zakazać, dopóki nie zostanie poprawione, ale Dekretu o zakazie nie należy publikować, natomiast należy pouczyć autora zgodnie z paragrafem IX konstytucji świętej pamięci papieża Benedykta XIV, która rozpoczyna się od słów Sollicita ac provida z roku 1753, na stronie 115 tomu IV Bullarium"55. Papież Klemens XIV tego samego dnia ową decyzję potwierdzi156. Przebieg sprawy podsumowano zwięźle:

Ks. Stanisław Konarski, zakonnik Szkół Pobożnych, opublikował w drukarni swego zakonu w Warszawie książeczkę $\mathrm{w} \mathrm{j}$. polskim, zatytułowaną 0 religii poczciwych ludzi. Dzieło to spotkało się w Polsce ze sprzecznymi ocenami, zależnie od ducha, jakim byli ożywieni jego czytelnicy i zależnie od stronnictwa, do którego przynależeli. Jedni, m.in. biskup poznański, książkę wychwalał i jej gratulował. Inni, wśród nich czterej teologowie wyznaczeni przez nuncjusza, ocenili ją surowo, uznając za pełną szkodliwych zdań i błędnych tez. Wobec tak rozbieżnych opinii nuncjusz mądrze zdecydował odesłać pracę do tutejszego Świętego Trybunału. [--] Jego Ekscelencja Patriarcha Lascaris, konsultor, podjął się trudnego i pracochłonnego zadania przetłumaczenia książki na j. włoski, przeprowadził też uczony i uzasadniony osąd, w którym oczyścił dzieło z błędnych zarzutów czterech polskich teologów, ale ze swej strony wskazał na pewne defekty, które w nim się znajdują ${ }^{57}$.

${ }^{54}$ Szczegółowe opisanie kolejnych posiedzeń wykroczyłoby poza ramy niniejszego artykułu. Znajdzie się w przygotowywanej kompletnej edycji akt procesu. Następstwo wydarzeń podsumowuje zwięźle Nota, [9 VII 1770], ACDF, C.L. 1770 [5], fol. 240r.

55 „Quod liber prohibeatur donec corrigatur, sed Decretum prohibitionis non publicetur, et interim moneatur auctor juxta ea quae praesentuntur in § IX Quoniam Constitionis S.M. Benedicti Papae XIV quae incipit «Sollicita ac provida» annis 1753 Tom[us] IV Bullar[ii] pag[ina] 115", [Protokół głosowania członków Kongregacji w obecności papieża], ACDF, Doctrinalia 032 (1769-1770), mazzo Num[ero] 38, fol. [1r.].

${ }^{56}$ Papieska aprobata orzeczenia kardynałów Kongregacji, podpisana przez asesora Św. Oficjum, Mons. Leonardo Antonellego, ACDF, C.L. 1770 (N.5), fol. 97v.

57 „Il P. Stanislao Konarschi religioso delle Scuole Pie pubblico colle stampe della Sua Religione in Varsavia un libretto in lingua polacca che ha per titolo «Della religione degl'uomini onesti». Quest'opera ha riscosso in Polonia un giudizio assai opposto, secondo lo spirito da cui erano i suoi lettori animati, e secondo l'impegno di quel partito a cui si erano abbandonati. Altri, e tra questi Mons. Vescovo di Posnania l'ha esaltata e le ha fatto applauso. Altri, e tra questi quattro teologi destinati da Mons. Nunzio 
Paragraf 9 konstytucji Sollicita ac provida, na który powoływano się w orzeczeniu w sprawie Konarskiego, stwierdzał, że w przypadku książki autora katolickiego, który dotąd cieszył się nieskazitelną opinią i dobrym imieniem, czy to z racji swych poprzednich książek, czy też swych obyczajów, o ile nie wykazano mu naprawdę poważnych błędów, należy zaaplikować kategorię prohibeatur donec corrigatur albo donec espurgetur. Książka O religii poczciwych ludzi została zatem formalnie zakwalifikowana do indeksu ksiąg zakazanych, lecz dekret taki miał pozostać utajniony w nadziei, że upomniany autor przyjmie werdykt, poprawi swoje dzieło i opublikuje je powtórnie. Gdyby z jakichś przyczyn nie zgodził się tego uczynić, dekret potępiający książkę miał zostać opublikowany. Podobnie miało stać się w sytuacji, gdyby się okazało, że pierwsze wydanie książki stało się ogólnodostępne i przyniosło poważne i powszechne szkody doktrynie katolickiej ${ }^{58}$.

Defekty w pracy Konarskiego zatem dostrzeżono i zażądano ich korekty, pod sankcją umieszczenia książki na indeksie, a jednocześnie ogólna opinia o jej treści była raczej łagodna. Podkreślano m.in.

l'hanno severamente lacerata giudicandola ripiena di massime perniciose e di erronee proposizioni. In tanta diversità d'opinioni ha saviamente pensato Mons. Nunzio di deferirla a questo S. Tribunale. [--] Mons. Patriarca Lascaris Consultore ha avuto il grave e laborioso incarico di tradurre in Italiano quest'operetta, e vi ha anche fatta una dotta e giudiziosa censura in cui vindicando il libro dalle mal opposte accuse de' quattro teologi di Polonia, ha poi anche a suo luogo rilevati i difetti che vi si contengono", Opinia wyrażona w Kongregacji św. Oficjum, ibidem, fol. 97r.

${ }^{58}$ Konstytucja deklarowała w punkcie 9: „Quoniam vero in Congregatione Indicis de sola librorum prohibitione agitur, nonnulla hoc loco adiungenda iudicavimus, eidem Congregationi potissimum usui futura, quae tamen ab altera etiam Congregatione Sancti Officii, dum in huius quoque generis causis se immiscet, ubi similes rerum circumstantiae se offerant, aeque observanda erunt. Quotiescumque agatur de libro auctoris catholici, qui sit integrae famae, et clari nominis, vel ob alios editos libros, vel forte ob eum ipsum, qui in examen adducitur, et hunc quidem proscribi oporteat; prae oculis habeatur, usu iamdiu recepta consuetudo prohibendi librum, adiecta clausula donec corrigatur, seu donec expurgetur, si locum habere possit, nec grave quidpiam obstet, quominus in casu de quo agitur, adhiberi valeat. Hac autem conditione proscriptioni adiecta, non statim edatur decretum, sed suspensa illius publicatione, res antea cum auctore, vel quovis altero pro eo agente et rogante communicetur, atque ei quid delendum, mutandum, corrigendumve fuerit, indicetur. Quod si nemo auctoris nomine compareat, vel ipse, aut alter pro eo agens, iniunctam correctionem libri detrectet, congruo definito tempore decretum edatur. Si vero idem auctor, eiusve procurator, Congregationis iussa fecerit, hoc est novam instituerit libri editionem cum opportunis castigationibus ac mutationibus, tunc supprimatur proscriptionis decretum; nisi forte prioris editionis exemplaria magno numero distracta fuerint; tunc enim ita decretum publicandum erit, ut omnes intelligant, primae editionis exemplaria dumtaxat interdicta fore, secundae vero iam emendatae permissa", H. Wolf, B. Schmidt, op.cit., s. 134, 136. 
uprzedzenia polskich teologów-cenzorów wobec autora, które sprawiły, że wszelkie niejednoznaczne stwierdzenia interpretowali w najgorszym możliwym znaczeniu. Wskazując na usterki, zrzucano je na karb niedostatecznej biegłości w kwestiach teologicznych, choć podejrzewano też rodzaj uległości politycznej wobec króla i środowiska dysydentów:

Nie można zaprzeczyć, że polscy cenzorzy, uprzedzeni co do intencji ojca Konarskiego, interpretują jego stwierdzenia w najgorszym sensie i w niektórych przypadkach przeinaczają je na jego niekorzyść. Ale jednocześnie nie można pominąć milczeniem faktu, że wspomniany o. Konarski, może z powodu niedostatecznego przygotowania teologicznego, popełnia błędy w tłumaczeniu zasad nauczania katolickiego oraz z powodu godnej napiętnowania życzliwości wobec heretyków w Polsce, bądź na skutek nadmiernej uległości królowi, tak bardzo i tak poufale miesza katolików z chrześcijańskimi heretykami, że daje słuszny powód swym przeciwnikom do podejrzeń, iż jego celem było bardziej usprawiedliwienie niecnych praw ostatnich sejmów w Polsce, przeciwko którym zaprotestowała już Stolica Apostolska, niż zwalczanie wolnomyśicieli, przeciwko którym pozornie pisze swoją książeczkę $e^{59}$.

Dodatkowym argumentem za podjęciem w sprawie Konarskiego decyzji o koniecznej korekcie dzieła były nie tyle błędy teologiczne, co kontekst polityczny kraju, w którym ono zostało opublikowane:

Gdyby książka o. Konarskiego została wydrukowana w jakimkolwiek innym kraju, niż Polska, oraz została napisana przez jakąkolwiek inną nację, niż polska, wytłumaczenie autora byłoby czymś łatwym. Ale publikacja w tym kraju i w obecnych okolicznościach sprawia, że nie można pozwolić na jej swobodną dystrybucję. Wszyscy znają aktualne nieszczęścia Polski, znana jest też ich przyczyna i nie wynika ona [z działalności] deistów tj. wolnomyślicieli, ale heretyków, tj. kalwinistów i luteran i innych podobnych sekciarzy. Deiści i wolnomyśliciele w Polsce nie stanowią zwartej grupy, nie mają protektorów, nie domagają się czegokolwiek. Heretycy przeciwnie, tworzą

59 „Non si puo negare, che i Sig[no]ri censori Polachi, prevenuti contra gl'intenzione del Padre Konarski interpretano nel peggior senso i di lui detti, e certamente in alcuni punti l'aggravano. Ma non sembra pure, che si possa negare, che il sudeto P. Konarski, forse per non avere sufficiente capitale di teologia, è molto diffettoso nel spiegare le massime della religione cattolica, e per una colpevole connivenza verso gl'eretici di Polonia, o per un spirito d'adulazione verso quel monarca, confonda talmetne, e con tanta affettazione i cattolici colli eretici cristiani, che dà tutto il motivo ai suoi accusatori, di fondatamente sospettare, che il di lui scopo tende più a giustificare le inique leggi degl'ultimi comizii di Polonia, contra i quali già protestò la Santa Sede, che ad impugnare i spiriti forti, contra dei quali fa mostra di scrivere il suo libretto", Opinia wyrażona w Kongregacji św. Oficjum, ACDF, Stanza Storica I-7-b., Nr XVII, fol. 2r.-v. 
znaczącą partię, są wspierani przez Moskwę, domagają się traktowania równego z katolikami. Ich pretensje opierają na fakcie bycia chrześcijanami, jakimi są prawie wszyscy heretycy ${ }^{60}$.

Po zaaprobowaniu przez papieża podjętej decyzji 10 sierpnia $1770 \mathrm{r}$. zakomunikowano ją prokuratorowi generalnemu pijarów. Miał on napisać w tej sprawie do Konarskiego, zachowując w najwyższym stopniu poufność korespondencji. Polskiemu pijarowi nakazywano przygotowanie drugiego wydania książki, zarówno w wersji łacińskiej, jak i polskiej, wskazano też bardzo precyzyjnie na zmiany, które należało poczynićc1. Sekretu rzeczywiście przestrzegano - w tym samym czasie o więcej informacji w wiadomej sprawie dopytywał się usilnie minister pełnomocny króla Stanisława Augusta, Tommaso Antici, powołując się na troskę polskiego króla o prawowierność publikacji Konarskiego. W Kurii Rzymskiej zalecono mu jedynie dalszą cierpliwość, nie podając szczegółów decyzji ${ }^{62}$.

19 października 1770 r. do Świętego oficjum wpłynął datowany 12 września tego roku list Stanisława Konarskiego do prokuratora generalnego pijarów ${ }^{63}$. Pełną wyrazów posłuszeństwa deklarację poddania się werdyktowi Kongregacji odczytano przed papieżem, ku jego wielkiej satysfakcji ${ }^{64} .1$ grudnia 1770 r. asesor Kongregacji Świętego Oficjum, Mons. Leonardo Antonelli, poinformował prokuratora generalnego pijarów, Gaetana Davini a S. Agnese, że treść poprawek zaproponowanych przez Konarskiego została przyjęta przez Ojca Świętego i zyskała

60 „Se il libro del P. Konarski fosse stampato in qualsivoglia altro luogo che in Polonia, e scritto per qualsisia altra nazione che per la Polacca, non sarebbe difficile lo scusar l'autore. Ma l'esser stampato in detto luogo, e nelle presenti circostanze è quel che fa, che il libro non si possa lasciar correre impunemente. Son note a ognuno le presenti calamità della Polonia, nota n'è altresì l'origine, che non deriva da Deisti, dai spiriti forti, ma bensì dagli eretici, cioè da Calvinisti, Luterani e altri settarii di simil sosta. I Deisiti e li spiriti forti in Polonia non fan corpo, non hanno chi gli assista, ne pretendon cosa alcuna. All'opposto gli eretici forman un partito considerabile, son assistiti dalla Moscovia, e pretendon di esser considerati nulla meno, che i Cattolici, afferrando uguaglianza con loro. Sull'esser essi Cristiani, come più o meno lo son tutti quanti gli Eretici fondan queste loro pretensioni”, Opinia wyrażona w Kongregacji św. Oficjum, ibidem, lipiec 1770, fol. 2r.

${ }^{61}$ Pismo do prokuratora generalnego pijarów, Gaetano Davini a S. Agnese, ACDF, C.L. 1770 (N.5), fol. 245r.-247v. Pełen wykaz poprawek sugerowanych Konarskiemu w Rzymie ukaże się w kompletnej edycji akt procesu.

${ }^{62}$ T. Antici do L. Antonellego, 8 VIII 1770, ibidem, fol. 250r.

${ }^{63}$ Stanisław Konarski do prokuratora generalnego pijarów, Gaetano Davini a S. Agnese, Warszawa, 12 IX 1770, ibidem, fol. 253r.-v., 262r.

${ }^{64}$ Pismo do prokuratora generalnego pijarów, Gaetano Davini a S. Agnese, listopad 1770, ibidem, fol. $254 \mathrm{r}$. 
aprobatę. Klemens XIV oczekiwał teraz planowanej publikacji w języku polskim i łacińskim drugiego wydania omawianego dzieła ${ }^{65}$.

Cytowany wyżej Teodor Nacher słusznie udowadniał, że wersja łacińska dzieła Konarskiego nie jest zwykłym tłumaczeniem wersji polskiej O religii poczciwych ludzi, lecz właściwie nową, poszerzoną wersją książki ${ }^{66}$. Nie mógł jednak zarówno on, jak i podążający jego śladem kolejni historycy, właściwie zinterpretować przyczyn tej różnicy. Dekretu Kongregacji Świętego Oficjum zawierającego treść prohibeatur donec corrigatur nie opublikowano, a sekretu w tej materii przestrzegano pilnie, nie dając publicznie sygnału, iż autor został upomniany za niektóre sformułowania, uznane za błędne z punktu widzenia nauczania katolickiego. Oczyszczenie Konarskiego z zarzutów nie nastąpiło na podstawie jakiegoś formalnego orzeczenia Stolicy Apostolskiej, lecz wynikało z faktu publikacji drugiej, poprawionej wersji książki w języku łacińskim.

Jak wiadomo, książka De religione honestorum hominum została opublikowana w Warszawie w 1771 r. - dołączony do dokumentacji procesu egzemplarz zamyka skoroszyt akt procesu Stanisława Konarskiego w Archiwum Kongregacji Doktryny Wiary (Święte Oficjum). 0 ile podsumowana zwięźle powyżej dokumentacja pozwala lepiej naświetlić faktyczny przebieg wydarzeń, które zaowocowały powstaniem łacińskiej wersji ostatniej książki Konarskiego, o tyle do wyjaśnienia pozostaje nadal fakt braku analogicznej wersji polskiej, której publikację dekret Kongregacji nakazywał, a i sam Konarski ją zapowiadał ${ }^{67}$. Być może nieszczęścia, które wkrótce spadły na Rzeczpospolitą oraz rychła śmierć pijara odwróciły uwagę Stolicy Apostolskiej od tej kwestii i sprawiły, że nie wyegzekwowano w pełni pierwotnych orzeczeń, zadowalając się publikacją wersji łacińskiej. Może do takiej poprawionej publikacji w języku polskim nie dopuścili Rosjanie? Konarski przyznawał, że pisząc w polskiej wersji książki ogólnie o „wierze chrześcijańskiej”, miał na uwadze środowiska dysydentów, którzy stanowili wspólny z katolikami front przeciw

${ }^{65}$ Pismo do prokuratora generalnego pijarów, Gaetano Davini a S. Agnese, 1 XII 1770, ibidem, fol. $264 \mathrm{r}$.

${ }^{66}$ I to znacznie poszerzoną, co Nacher zdawał się podkreślać, nie znając jednak przyczyny takiej obfitości. Tymczasem Konarski, odnosząc się do zasugerowanych poprawek, stwierdzał: „Quae adeo facilia mihi facta sunt, ut ea, quae censura iubet, mutanda, rescindenda et addenda nullo negotio imo perlibenter suscipiam; magisque mihi fixum sit, hac in parte abundare, quam deficere [wyróżnienie - P.Z.]", S. Konarski do prokuratora generalnego pijarów, Warszawa, 12 IX 1770, ibidem, fol. 253r. Konarski deklarował, że woli przesadzić w ilości poprawek, niż czegokolwiek zaniedbać!

${ }^{67}$ „Reimprimi deinde, mox ut Roma super mittendi a me correctionibus responsum habuero, et latinam traductionem, et poloni cum libellum curabo", ibidem. 
deistom ${ }^{68}$. W jedynej znanej na chwilę obecną osobistej reakcji na dekret Kongregacji, tj. w cytowanym liście do prokuratora generalnego pijarów z 12 września 1770 r., Konarski nie odniósł się do aluzji o ewentualny polityczny podtekst dzieła, pozostając na gruncie teologii i polemiki z deistami.

Szczegółowa analiza dokumentacji archiwalnej, jedynie zasygnalizowanej w niniejszym tekście, ukazuje zasadniczą zgodność stylu myślenia Stanisława Konarskiego z nurtem oświecenia chrześcijańskiego, które na dobre zagościło w Rzymie w okresie pontyfikatu Benedykta XIV. Reforma procedur związanych z indeksem ksiąg zakazanych, wdrożona przez tego papieża, pozwoliła katolickim autorom na odważniejszą interakcję ze współczesnymi prądami umysłowymi. W Kurii Rzymskiej istniała jednocześnie świadomość szczególnego kontekstu społeczno-politycznego Rzeczypospolitej, w której sąsiednie potęgi manipulowały kwestiami wyznaniowymi nie dla idei dobrze rozumianej tolerancji, ale dla politycznego podporządkowania sobie kraju postrzeganego jako katolicki. Wynikła z tego decyzja, należąca do rzadkości w przypadku polskich autorów, by książkę 0 religii poczciwych ludzi w sekrecie zakwalifikować do indeksu ksiąg zakazanych. Reakcja Stanisława Konarskiego i całkowite przyjęcie rzymskich nakazów pozwoliło na utrzymanie tego sekretu przez długie wieki, co przypieczętowało możliwość w pełni katolickiej lektury książki pijara przez kolejne pokolenia.

\section{Streszczenie}

Autorzy piszący o Stanisławie Konarskim i jego osiągnięciach wymieniali wśród nich dzieło 0 religii poczciwych ludzi. Jego publikacja w 1769 r. pogłębiła znany w historiografii kryzys w relacjach Stanisława Konarskiego z nuncjuszem Angelo Marią Durinim, który zadenuncjował go w Kurii Rzymskiej. Nuncjusz wymienił książkę wśród przykładów negatywnego oddziaływania pijara na młodzież poprzez propagowanie tolerantyzmu i nowoczesnej filozofii. Za pośrednictwem publikacji Augustina Theinera, który obficie korzystał z depesz Duriniego, ten pogląd przejęło kilku polskich autorów w XIX w., krytycznie oceniając znaczenie Konarskiego dla kultury i społeczeństwa Rzeczypospolitej, m.in. z uwagi na odejście od wierności katolickiej tradycji. Inni bronili pijara stwierdzając, że dzieło 0 religii poczciwych ludzi zostało niesprawiedliwie zinterpretowane przez nuncjusza, a Konarski udowodnił swoją prawowierność, tłumacząc książkę na język łaciński, co pozwoliło na oczyszczenie go w Rzymie z wszelkich zarzutów. Z czasem dostrzeżono, że wersja

68 „Istum quidem ita ego confeceram, ut etiam ab acatholicis sine fastidio et irritatione eorum legi posset, cum et illorum causa contra theistas sit cum nostra fere communis, sed cum haec ratio discendi Romae non probetur, malo accatholicis displicere quam ulli bonorum Catholicorum, aut quam ansam dare cuiuscumque contra me malignitati", ibidem. 
łacińska nie jest dokładnym tłumaczeniem polskiego oryginału, co niektórzy uznali za celowe fałszerstwo Konarskiego, by zmylić Kurię Rzymską, inni zaś uważali tekst łaciński za poszerzoną parafrazę tekstu polskiego, przy czym uznawali katolicką ortodoksję obu wersji. Pomimo tych dyskusji, w całej dotychczasowej historiografii nie zdołano ukazać faktycznego przebiegu sporu oraz prawdziwej genezy drugiego wydania książki. Uzyskany niedawno dostęp do źródeł Archiwum Kongregacji Doktryny Wiary pozwolił na wgląd w akta procesu, który faktycznie miał miejsce w Świętym Oficjum w sprawie Konarskiego i jego publikacji. Na potrzeby procesu sporządzono włosko-łacińskie rękopiśmienne tłumaczenie książki polskiego pijara. Mając do dyspozycji opinie polskich teologów, przesłane przez nuncjusza Duriniego, przekazano tekst książki do dalszej recenzji teologom rzymskim. W oparciu o całość tak zgromadzonego materiału recenzyjnego Giorgio Maria Lascaris, na polecenie Świętego Oficjum, przygotował obszerny raport, w którym oczyszczał Konarskiego z większości zarzutów, uznając jednocześnie dwuznaczność niektórych sformułowań. Na dalszym etapie procesu konsultorzy Kongregacji Świętego Oficjum polecili przygotowanie listy poprawek, zaakceptowanej następnie przez kardynałów. Ostatnie posiedzenie w obecności papieża zakończyło się werdyktem o zastosowaniu wobec książki Konarskiego 9. paragrafu konstytucji Benedykta XIV Sollicita ac provida: autorowi polecano poprawienie książki oraz publikację drugiego wydania. Gdyby tego nie zrobił, pierwsze wydanie zostałoby umieszczone na indeksie ksiąg zakazanych. Ponieważ Konarski werdykt przyjął i swoją książkę poprawil, całość dotychczasowej procedury miała pozostać utajniona. Konkludując: w Rzymie uznano przesadność większości zarzutów postawionych w Polsce Konarskiemu. Jednocześnie nakazano mu poprawienie konkretnych fragmentów jego książki, które mogły budzić zastrzeżenia z uwagi na dwuznaczne brzmienie.

\section{Stanisław Konarski's On the Religion of Honest Men - between Historiography and New Establishments Based on the Records of the Congregation for the Doctrine of the Faith}

The authors writing about Stanisław Konarski and his achievements mentioned the text 0 religii poczciwych ludzi (On the Religion of Honest Men). Its publication in 1769 aggravated a crisis, known in historiography, in relations between Konarski and Nuncio Durini, who denounced him to the Roman Curia. The nuncio cited the book among the examples of the Piarist's negative influence on the youth by promoting tolerantism and modern philosophy. Through the publications of Augustin Theiner, who made extensive use of Durini's dispatches, this view was adopted by several Polish authors in the nineteenth century, who were critical of Konarski's significance for the culture and society of the Commonwealth, among other things, for his departure from loyalty to Catholic tradition. Others defended the Piarist, arguing that the nuncio unjustly interpreted Konarski's treatise On the Religion of Honest Men. Konarski proved his orthodoxy by translating his text into Latin, which made it possible for him to be cleared of all charges in Rome. With time, it was noticed that the Latin version was not an exact translation of the Polish 
original, which some considered to be Konarski's deliberate forgery to mislead the Roman Curia. Others, however, regarded the Latin text as an extended paraphrase of the Polish text and acknowledged the Catholic orthodoxy of both versions.

Despite these discussions, all historiography to date has failed to reveal the actual course of the dispute and the true genesis of the second edition of the book. The recently gained access to the sources kept in the Archive of the Congregation for the Doctrine of the Faith permitted insight into the trial records taking place at the Sanctum Officium regarding Konarski and his publication. An Italian-Latin manuscript translation of Konarski's treatise was prepared for the trial. Having at their disposal opinions of Polish theologians, sent by Nuncio Durini, the book's text was forwarded to Roman theologians for further review. Based on all the review material gathered in this way, Georgius Maria Lascaris, at the behest of the Sanctum Officium, prepared an extensive report in which he cleared Konarski of most charges while acknowledging the ambiguity of some formulations. At a later stage of the process, the Congregation of the Sanctum Officium consultants ordered a list of corrections to be made by Konarski, subsequently accepted by the cardinals. The final session in the pope's presence concluded with the verdict that the ninth paragraph of Benedict XIV's constitution Sollicita ac provida should be applied to Konarski's book: the author was instructed to correct the book and to publish its second edition. Had he not done so, the first edition would have been placed on the Index of Prohibited Books. Since Stanisław Konarski accepted the verdict and corrected his book, the entire procedure was to remain secret. In conclusion: Rome recognised the exaggeration of most of the charges brought against Konarski in Poland. At the same time, he was ordered to correct specific fragments of his book that could raise objections because of their ambiguous wording.

\section{Bibliografia}

\section{Edycje źródłowe}

Krajewski Michał Dymitr, Pochwała Stanisława Hieronima Konarskiego, Warszawa 1783. Leszczyński Stanisław, Des désirs, w: Ouvres du philosophe Bienfaisant, t. 1, Paris 1763, s. 306-325.

Leszczyński Stanisław, L'incrédulité combattue par le simple bon sens, Nancy 1760. Leszczyński Stanisław, Le philosophe chrétien, [b.m.] 1749.

Leszczyński Stanisław, La Religion [b.m., b.d.], w: Ouvres du philosophe Bienfaisant, t. 4, Paris 1763, s. 171-186.

Nacher Teodor, Dwa dzieła Konarskiego: 0 religii poczciwych ludzi 1769 i De religione honestorum hominum 1771, Stryj 1883.

Polignac Melchior de, Anti-Lucrèce, poème sur la religion naturelle, tłum. Jean-Pierre de Bougainville, Paris 1749.

Polignac Melchior de, Anti-Lucretius, sive de Deo et natura, t. 1-2, Paris 1745.

Theiner Augustin, Histoire du pontificat de Clément XIV, d'après des documents inédits, [traduite de l'allemand sous les yeux de l'auteur par Paul de Geslin], t. 1, Paris 1852. 
Wilczek Ignacy, Carmina. Nova Editio Altera Sui Parte Auctior Et Emendatior, Calissii 1785.

\section{Opracowania}

Chachulski Tomasz, Stanisław Konarski, DiG, Warszawa 2000.

Deszczyńska Martyna, Polskie kontroświecenie, BEL Studio, Warszawa 2011.

Hinz Henryk, Deizm, w: Słownik literatury polskiego Oświecenia, red. Teresa Kostkiewiczowa, Ossolineum, Wrocław 1977, s. 69-73.

Konopczyński Władysław, Stanisław Konarski, Kasa im. Mianowskiego - Instytut Popierania Nauki, Warszawa 1926.

Łukowski Jerzy, Od Konarskiego do Kołtątaja - czyli od realizmu do utopii, w: Trudne stulecia. Studia z dziejów XVII i XVIII wieku. Ofiarowane profesorowi Jerzemu Michalskiemu w siedemdziesiątą rocznice urodzin, red. Łukasz Kądziela, Wojciech Kriegseisen, Zofia Zielińska, Semper, Warszawa 1994, s. 184-194.

Nowak-Dłużewski Juliusz, Stanisław Konarski, Pax, Warszawa 1989.

Pietrzak Jarosław, Testament patriarchy jerozolimskiego Jerzego Marii Laskarysa ze zbiorów Archiwum Zamku Królewskiego w Warszawie - Muzeum, „Kronika Zamkowa. Roczniki” 2015, 2 (68), s. 297-343.

Sinko Tadeusz, Polski Anti-Lukrecjusz, „Rozprawy Akademii Umiejętności. Wydział Filologiczny", Seria 3, 4 [49], Kraków 1911, s. 286-399.

Skoczyński Jan, Woleński Jan, Historia filozofii polskiej, WAM, Kraków 2010.

Stopniak Franciszek, Laskarys (Lascaris) Jerzy Hieronim Maria Wojciech (1706-1795), PSB, t. 16, Wrocław-Warszawa-Kraków 1971, s. 519-520.

Treger Bronisław, Konarski o filozofach, w: Stanisław Konarski pedagog - polityk - filozof, red. Jadwiga Ziętarska, WP UW, Warszawa 2004, s. 95-104.

Wąsik Wiktor, Historia filozofii polskiej, t. 1: Scholastyka, renesans, oświecenie, Pax, Warszawa 1958.

Wolf Hubert, Schmidt Bernward, Benedikt XIV und die Reform des Buchzensurverfahrens. Zu Geschichte und Rezeption von „Sollicita ac provida”, Brill, Paderborn 2011. Wolf Hubert, Storia dell'Indice. Il Vaticano e i libri proibiti, Donzelli Editore, Roma 2006.

Biogram: prof. UAM dr hab. Paweł Zając OMI, Zakład Teologii Historycznej Wydziału Teologicznego Uniwersytetu im. Adama Mickiewicza w Poznaniu. Zainteresowania badawcze: historia nuncjatury warszawskiej w XVIII w.; kontakt: pawel. zajac@amu.edu.pl.

Author: Paweł Zając OMI, PhD, professor at the Adam Mickiewicz University in Poznań, Department of Historical Theology, at the Faculty of Theology. Research interests: history of the Warsaw Nunciature in the eighteenth century; contact: pawel.zajac@amu.edu.pl. 